\title{
Bør blodtrykksbehandling ved diabetes være mer intensiv?
}

\section{Pasienter med type 2-diabetes har økt risiko for hjerteinfarkt. Bør hyper- toni hos disse pasientene behandles mer intensivt enn hva som er vanlig i dag?}

I en ny studie publisert i tidsskriftet $B M J$ ble over 187000 personer med diagnosen type 2-diabetes i det svenske diabetesregisteret inkludert (1). Pasientene måtte ha hatt diagnosen i minst ett år, og de eldre enn 75 år og de med etablert hjerte- og karsykdom eller annen alvorlig sykdom ble ekskludert. Median observasjonstid var fem år.

Gruppen med lavest systolisk blodtrykk (dvs. 110-119 mm Hg) hadde lavere risiko for en rekke endepunkter enn dem med systolisk blodtrykk på 130-139 mm Hg: ikkedødelig hjerteinfarkt (hasardratio $0,76 \%$; $95 \%$ KI 0,64-0,91), totalt antall hjerteinfarkt $(0,85 ; 0,72-0,99)$, ikke-dødelig hjerte- og karsykdom $(0,82 ; 0,72-0,93)$, total hjerte- og karsykdom $(0,88 ; 0,79-0,99)$ og ikke-døde- lig koronarsykdom $(0,88 ; 0,78-0,99)$. Gruppen med høyt systolisk blodtrykk, dvs. $>150$ $\mathrm{mm} \mathrm{Hg}$, hadde forhøyet risiko for alle endepunkter, mens gruppen med lavest blodtrykk hadde signifikant økt risiko for hjertesvikt og totaldødelighet. Forfatterne konkluderer med at de fant en $\mathrm{J}$-formet kurve for sammenhengen mellom systolisk blodtrykk og totaldødetrykk og hjerneslag, hjerteinfarkt og koronarsykdom.

- Denne studien er vel gjennomført og har høy kvalitet, sier Bjørn Gjelsvik, spesialist $\mathrm{i}$ allmennmedisin og førsteamanuensis ved Universitetet i Oslo. - Forfatterne fant altså ikke en J-formet risikokurve som er påvist i tidligere studier, dvs. at risiko for lighet og hjertesvikt, men ikke mellom blod-

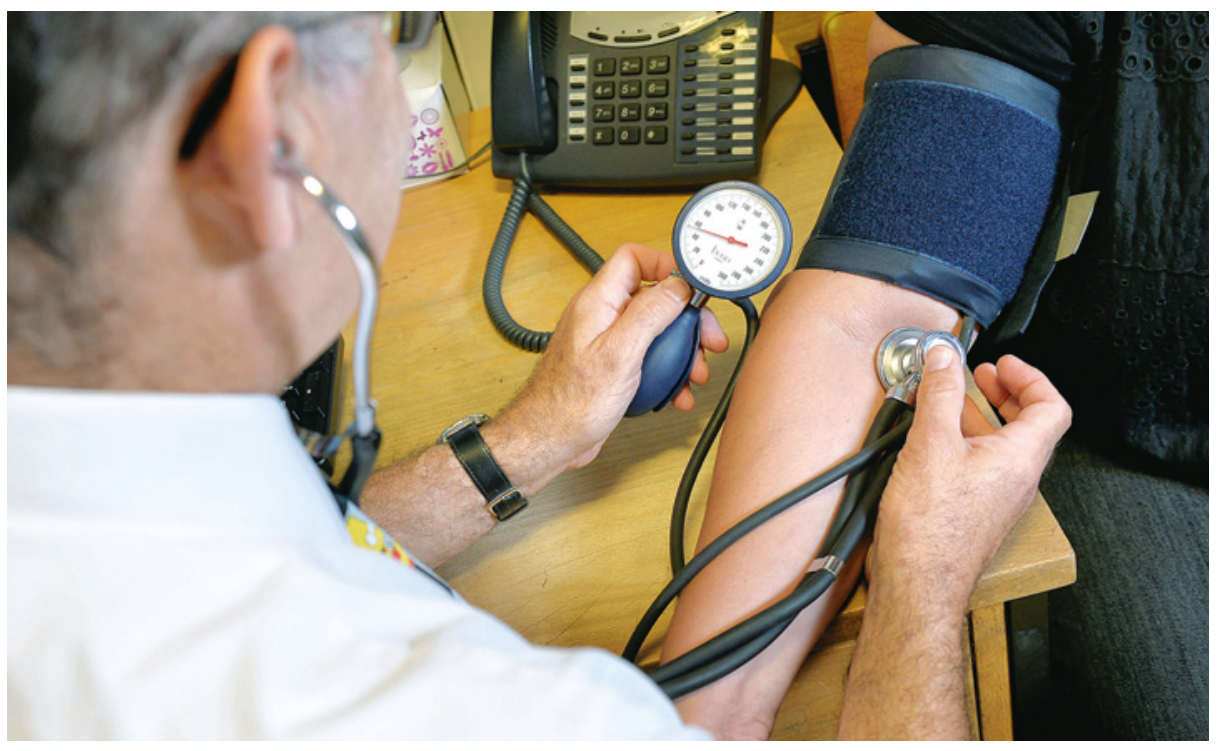

Illustrasjonsfoto: PA Photos/Scanpix hendelser er økt både for dem med høyt og dem med lavt blodtrykk. Det har vært postulert at økt risiko hos dem med lavest blodtrykk skyldes annen sykdom, slik som kreft eller hjertesykdom.

- I den svenske studien er disse gruppene tatt ut. Derfor mener forfatterne at manglende J-formet kurve for kardiovaskulære hendelser tyder på at det er komorbiditet og ikke blodtrykksbehandling som forklarer den økte sykdomsrisikoen hos dem med lavest trykk i andre studier, sier han.

Gjelsvik påpeker at gjennomsnittlig antall blodtrykksmedisiner var lavest hos dem med lavest blodtrykk, og at det indikerer at blodtrykket ikke var en risikofaktor i denne gruppen.

- Det var mindre forskjell i risiko for hendelser i gruppen med blodtrykk mellom 120-129 mm Hg og 140-149 mm Hg, men også her viste trenden gunstigere resultat for gruppen med lavere blodtrykk. Studien viser riktignok at lavere blodtrykk hos pasienter med diabetes uten andre risikofaktorer er assosiert med lavere risiko for flere endepunkter, men den viser ikke at blodtrykksbehandling i seg selv er assosiert med bedre prognose, sier Gjelsvik. - Det at studien likevel viser en J-formet kurve for totaldødelighet, betyr at resultatene ikke uten videre er et argument for lavere målblodtrykk hos pasienter med diabetes.

Gjelsvik mener at studien er relevant for norske forhold og et argument for å gjennomføre randomiserte studier for å avklare hva som er optimalt behandlingsmål for blodtrykk hos pasienter med diabetes.

\section{Ketil Slagstad \\ Tidsskriftet}

Litteratur

1. Adamsson Eryd S, Gudbjörnsdottir S, Manhem K et al. Blood pressure and complications in individuals with type 2 diabetes and no previous cardiovascular disease: national population based cohort study. BMJ 2016; 354: i4070 